Article

\title{
Impact of Bicarbonate- $\beta$-Lactam Exposures on Methicillin-Resistant Staphylococcus aureus (MRSA) Gene Expression in Bicarbonate- $\beta$-Lactam-Responsive vs. Non-Responsive Strains
}

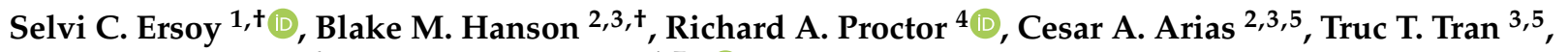 \\ Henry F. Chambers ${ }^{6}$ and Arnold S. Bayer ${ }^{1,7, *(1)}$ \\ 1 The Lundquist Institute, Torrance, CA 90502, USA; selvi.ersoy@lundquist.org \\ 2 Center for Infectious Diseases, School of Public Health, University of Texas Health Science Center, \\ Houston, TX 77030, USA; Blake.Hanson@uth.tmc.edu (B.M.H.); CAArias@houstonmethodist.org (C.A.A.) \\ 3 Center for Antimicrobial Resistance and Microbial Genomics, Division of Infectious Diseases, \\ University of Texas Health Science Center at Houston McGovern Medical School, Houston, TX 77030, USA; \\ tttran4@houstonmethodist.org \\ 4 School of Medicine and Public Health, University of Wisconsin, Madison, WI 53706-152, USA; rap@wisc.edu \\ 5 Houston Methodist Hospital, Houston, TX 77030, USA \\ 6 UCSF School of Medicine, San Francisco, CA 94143, USA; Henry.Chambers@ucsf.edu \\ check for \\ updates \\ Citation: Ersoy, S.C.; Hanson, B.M.; \\ + Authors contributed equally to this work.
} Proctor, R.A.; Arias, C.A.; Tran, T.T.; Chambers, H.F.; Bayer, A.S. Impact of Bicarbonate- $\beta$-Lactam Exposures on Methicillin-Resistant Staphylococcus aureus (MRSA) Gene Expression in Bicarbonate- $\beta$-Lactam-Responsive vs. Non-Responsive Strains. Genes 2021, 12, 1650. https://doi.org/10.3390/ genes 12111650

Academic Editors: Patrice Francois and Nathalie L. van Der Mee-Marquet

Received: 19 August 2021

Accepted: 8 October 2021

Published: 20 October 2021

Publisher's Note: MDPI stays neutral with regard to jurisdictional claims in published maps and institutional affiliations.

Abstract: Methicillin-resistant Staphylococcus aureus (MRSA) infections represent a difficult clinical treatment issue. Recently, a novel phenotype was discovered amongst selected MRSA which exhibited enhanced $\beta$-lactam susceptibility in vitro in the presence of $\mathrm{NaHCO}_{3}$ (termed ${ }^{\prime} \mathrm{NaHCO}_{3}$ responsiveness'). This increased $\beta$-lactam susceptibility phenotype has been verified in both ex vivo and in vivo models. Mechanistic studies to-date have implicated $\mathrm{NaHCO}_{3}$-mediated repression of genes involved in the production, as well as maturation, of the alternative penicillin-binding protein (PBP) 2a, a necessary component of MRSA $\beta$-lactam resistance. Herein, we utilized RNA-sequencing (RNA-seq) to identify genes that were differentially expressed in $\mathrm{NaHCO}_{3}$-responsive (MRSA 11/11) vs. non-responsive (COL) strains, in the presence vs. absence of $\mathrm{NaHCO}_{3}-\beta$-lactam co-exposures. These investigations revealed that $\mathrm{NaHCO}_{3}$ selectively repressed the expression of a cadre of genes in strain 11/11 known to be a part of the sigB-sarA-agr regulon, as well as a number of genes involved in the anchoring of cell wall proteins in MRSA. Moreover, several genes related to autolysis, cell division, and cell wall biosynthesis/remodeling, were also selectively impacted by $\mathrm{NaHCO}_{3}-\mathrm{OXA}$ exposure in the $\mathrm{NaHCO}_{3}$-responsive strain MRSA 11/11. These outcomes provide an important framework for further studies to mechanistically verify the functional relevance of these genetic perturbations to the $\mathrm{NaHCO}_{3}$-responsiveness phenotype in MRSA.

Keywords: Methicillin-resistant Staphylococcus aureus (MRSA); $\beta$-lactam susceptibility; sodium bicarbonate $\left(\mathrm{NaHCO}_{3}\right)$; RNA-sequencing (RNA-seq)

\section{Introduction}

The rise of antibiotic-resistant bacteria has increasingly threatened healthcare initiatives worldwide [1-4]. In particular, methicillin-resistant Staphylococcus aureus (MRSA) is a major clinical pathogen, causing a wide variety of severe infections, with relatively limited treatment options, poor patient outcomes, and increased healthcare-associated costs [5-8]. MRSA strains are traditionally considered as "resistant" to nearly all $\beta$-lactams (the treatment of choice for methicillin-susceptible S. aureus [MSSA]) $[9,10]$. Standard treatment options for MRSA, such as vancomycin or daptomycin, tend to be less effective, less well 
tolerated (in terms of side effects and toxicities) and more expensive than standard-of-care $\beta$-lactams as used for MSSA infections [11-14].

Recently, a novel $\beta$-lactam susceptibility phenotype was discovered among MRSA strains, termed 'bicarbonate $\left[\mathrm{NaHCO}_{3}\right]$-responsiveness', wherein certain MRSA strains become sensitized to $\beta$-lactam antibiotics in vitro in the presence of $\mathrm{NaHCO}_{3}[15,16]$. This phenotype was relatively widespread among a small collection $(n=58)$ of US bloodstream isolates (ranging from $33-75 \%$ for oxacillin and cefazolin, respectively [16]). Importantly, the translatability of this phenotype has been verified both ex vivo (in simulated endocarditis vegetations [SEV] models) and in vivo (in experimental infective endocarditis models) $[15,17]$. To-date, the potential mechanisms of this phenotype have focused on the impact of $\mathrm{NaHCO}_{3}$ on mecA expression/PBP2a protein production, as well as upon genes associated with PBP2a maturation and functionality $[15,18]$. However, these mechanistic studies have predominantly centered on targeted investigations of well-characterized genes already known for their involvement in $\beta$-lactam resistance in MRSA, rather than a more unbiased and global consideration of genes that are selectively impacted among $\mathrm{NaHCO}_{3}$-responsive vs. non-responsive MRSA strains.

In the present investigation, we have utilized RNA-sequencing (RNA-seq) methods to identify a broader repertoire of genes likely involved in the $\mathrm{NaHCO}_{3}$-responsive vs. non-responsive phenotypes. We concentrated on identifying genes which were selectively expressed during $\mathrm{NaHCO}_{3}$ - $\beta$-lactam co-exposures, comparing a prototype $\mathrm{NaHCO}_{3}$ responsive strain (MRSA 11/11) to a prototype non-responsive strain (COL) $[15,17,18]$. These RNA-seq analyses revealed a number of differentially and selectively expressed genes in the $\mathrm{NaHCO}_{3}$-responsive strain, with several noteworthy gene cadres, including: (i) genes within the sigB-sarA-agr regulatory axis; (ii) cell wall-anchored/peptidoglycanassociated genes; and (iii) genes involved in either global or divisome-specific autolysis.

\section{Materials and Methods}

\subsection{Bacterial Strains and Growth Conditions}

MRSA strains MRSA 11/11 (USA300) and COL (USA100) were utilized as representative $\mathrm{NaHCO}_{3}$-responsive and -non-responsive strains, respectively [15]. These two prototype strains have been used in a number of our prior investigations related to $\mathrm{NaHCO}_{3}$ responsiveness in vitro, ex vivo and in vivo $[15,17,18]$. These strains have the following mecA, agr, spa and CC types: SCCmec IV, agr I, t008, CC8 (MRSA 11/11); and SCCmec I, agr I, t008, CC8 (COL).

Strains were stored at $-80{ }^{\circ} \mathrm{C}$ until thawed for use, and isolated on tryptic soy agar (TSA). Strains were grown in cation-adjusted Mueller Hinton Broth (CA-MHB; Difco $)+100 \mathrm{mM}$ Tris $(\mathrm{pH} 7.3 \pm 0.1)$ with or without $44 \mathrm{mM} \mathrm{NaHCO}_{3}$ or CA-MHB $+100 \mathrm{mM}$ Tris $(\mathrm{pH} 7.3 \pm 0.1)+2 \% \mathrm{NaCl}+\frac{1}{2} \mathrm{x}$ the minimum inhibitory concentration (MIC) of oxacillin (OXA), with or without $44 \mathrm{mM} \mathrm{NaHCO}_{3}$ to generate RNA to compare the impact of $\mathrm{NaHCO}_{3}$ alone or the impact of $\mathrm{NaHCO}_{3}+\mathrm{OXA}$, respectively, by RNA-seq. OXA concentrations for MRSA 11/11 were $16 \mu \mathrm{g} / \mathrm{mL}$ (CA-MHB Tris) and $0.25 \mu \mathrm{g} / \mathrm{mL}$ (CA-MHB Tris $+44 \mathrm{mM} \mathrm{NaHCO}_{3}$ ) (representing $\frac{1}{2}$ the MIC as determined for this strain by broth microdilution in media without and with $\mathrm{NaHCO}_{3}$, respectively [15]); OXA concentrations for COL were $256 \mu \mathrm{g} / \mathrm{mL}$ for both distinct growth conditions. We have used the above $\mathrm{NaHCO}_{3}$ and OXA concentrations in our prior studies [15-19]. Although this $\mathrm{NaHCO}_{3}$ concentration ( $44 \mathrm{mM})$ is above human blood levels, it replicates tissue levels [20], and maximizes the $\mathrm{NaHCO}_{3}$-responsiveness phenotype $[15,19]$.

\subsection{RNA Isolation, Library Construction, Sequencing and Analysis}

To obtain RNA, strains were grown in CA-MHB $100 \mathrm{mM}$ Tris $\pm 44 \mathrm{mM} \mathrm{NaHCO}$ overnight $(\mathrm{O} / \mathrm{N})$, then diluted 1:50 into $25 \mathrm{~mL}$ of either the same $\mathrm{O} / \mathrm{N}$ growth medium or $\mathrm{O} / \mathrm{N}$ growth medium supplemented with $2 \% \mathrm{NaCl}$ and $\frac{1}{2} \times$ OXA MIC concentrations (as indicated above). Cultures were then grown for $4 \mathrm{~h}$ at $37^{\circ} \mathrm{C}$ with aeration (to reach an $\mathrm{OD}_{600}$ $\sim 0.5$ ), and total RNA was harvested by mechanical disruption by FastPrep disruption (MP 
Biomedicals, Irvine, CA, USA), followed by column isolation (Qiagen, Germantown, MD, USA), and treatment with Turbo DNAse (Invitrogen, Waltham, MA, USA) to remove DNA from sample [15]. Ribosomal RNA was depleted using the Ribo-Zero Magnetic Bead rRNA Removal Kit (Illumina, San Diego, CA, USA) and prepared for sequencing using the Illumina Stranded Total RNA Prep Kit (Illumina, San Diego, CA, USA). Extracted RNA quality was assessed with an Agilent TapeStation 4200 (Agilent, Santa Clara, CA, USA) using an RNA ScreenTape, assuring an RNA Integrity Number (RIN score) above 6 before moving into library preparation. Following cDNA conversion, fragment sizes were assessed using an Agilent TapeStation 4200 and a High Sensitivity DNA ScreenTape, and DNA concentration was assessed using a Qubit (Thermo Fisher Scientific, Waltham, MA, USA) and dsDNA HS Assay kit. Sequencing libraries were pooled at equimolar concentrations and sequenced on an Illumina HiSeq 4000 (Illumina, San Diego, CA, USA) using $2 \times 150$ paired end reads. Sequencing adapters and low-complexity reads were removed using Trimmomatic v0.38 [21], and aligned to the ASM1346v1 and ASM1204v1 RefSeq genomes with Bowtie2 v2.3.4.2 for MRSA 11/11 and COL, respectively [22]. Transcripts were assembled using Cufflinks v2.2.1, and CummeRbund v2.32.0 [23]. Two biological replicates were assessed in technical duplicate for each strain and indicated growth condition. Expression data for these samples containing $\mathrm{NaHCO}_{3}$ are currently available in the NCBI Sequence Read Archive (SRA) database under the accession numbers SAMN21542115 (MRSA 11/11 CA-MHB Tris + $\left.\mathrm{NaHCO}_{3}\right)$, SAMN21542148 (MRSA 11/11 CA-MHB Tris + $\left.\mathrm{OXA}+\mathrm{NaHCO}_{3}\right), \mathrm{SAMN} 21542116\left(\mathrm{COL} \mathrm{CA}-\mathrm{MHB}\right.$ Tris $\left.+\mathrm{NaHCO}_{3}\right)$, and SAMN21542147 $\left(\mathrm{COL} C A-\mathrm{MHB}\right.$ Tris $\left.+\mathrm{OXA}+\mathrm{NaHCO}_{3}\right)$. Codification of the accession numbers for sequence read data-basing for samples that do not contain $\mathrm{NaHCO}_{3}(\mathrm{MRSA} 11 / 11 \mathrm{CA}-\mathrm{MHB}$ Tris, MRSA 11/11 CA-MHB Tris + OXA, COL CA-MHB Tris, COL CA-MHB Tris + OXA), are currently in-progress and will be made available by contacting the lead Author (S.C.E.), at the following email address (selvi.ersoy@lundquist.org). "Differentially and selectively expressed genes" in our study represented those genes which exhibited a significant level of differential expression in the presence of $\mathrm{NaHCO}_{3} \pm \mathrm{OXA}$ exposure compared to media without $\mathrm{NaHCO}_{3}$ for the responsive strain, MRSA 11/11 vs. the non-responsive COL strain ( $\geq 2$-fold). Thus, this definition explicitly eliminated genes which were differentially and concordantly expressed under these conditions in MRSA 11/11 as well as in COL. For selected analyses, we catalogued genes which were differentially expressed by $\geq 5$-fold.

Kyoto Encyclopedia of Genes and Genomes (KEGG) metabolic pathways and annotations for differentially abundant genes were mapped using KOBAS v3.0 [24].

\section{3. qRT-PCR Validation of Select Genes}

Total RNA was isolated from MRSA $11 / 11$ and COL log phase cells $\left(\mathrm{OD}_{600}=0.5\right)$ grown in CA-MHB $100 \mathrm{mM}$ Tris $+2 \% \mathrm{NaCl}+\frac{1}{2} \times \mathrm{MIC}$ OXA $\pm 44 \mathrm{mM} \mathrm{NaHCO} 3$ as previously described [15]. Briefly, RNA was extracted by column isolation (Qiagen, Germantown, MD, USA) following mechanical disruption by FastPrep (MP Biomedicals, Irvine, CA, USA). Total RNA was treated with Turbo DNAse (Invitrogen, Waltham, MA, USA) and reverse transcribed by random hexamers to generate a cDNA library with SuperScript IV (Invitrogen, Waltham, MA, USA).

Following RNA-seq analyses, we selected five genes from the overall repertoire of differentially expressed genes for qRT-PCR validations, representing broad categories of bacterial factors, including: i) peptidoglycan synthesis ( $p b p 2$ and $d d h$ ); ii) autolysis (atl and $s c e D)$; and iii) virulence $(f n b A)$. The primers listed in Table S1 were used to amplify each gene-of-interest to determine their relative expressions. The gene $g y r B$ was used as a housekeeping gene to normalize transcript abundance. The qRT-PCR was carried out on a StepOne thermocylcer (ThermoFisher, Waltham, MA, USA) and analyzed with StepOne Software. Relative gene expression was calculated using the $2^{-\Delta \Delta C}$ method from two independent biological replicates performed in triplicate on at least two separate runs for each strain/condition. Relative gene expression in CA-MHB $100 \mathrm{mM}$ Tris+2\% $\mathrm{NaCl}+\frac{1}{2} \times \mathrm{MIC} \mathrm{OXA}+44 \mathrm{mM} \mathrm{NaHCO} 3$ was normalized to CA-MHB $100 \mathrm{mM}$ Tris $+2 \%$ 
$\mathrm{NaCl}+\frac{1}{2} \times \mathrm{MIC}$ OXA for each gene, with expression in the latter condition set equal to 1.0. statistical significances related to relative expression profiles were determined by a Student's $t$-test, with a $p$ value of $\leq 0.05$ considered 'significant'.

\section{Results and Discussion}

\subsection{Differentially Expressed Genes by $\mathrm{RNA}$-seq in $\mathrm{NaHCO}_{3}$-responsive vs. Non-responsive Strains}

RNA-seq analysis was carried out on two prototypical MRSA strains, MRSA 11/11 ( $\mathrm{NaHCO}_{3}$-reponsive) and $\mathrm{COL}\left(\mathrm{NaHCO}_{3}\right.$-non-responsive), for two distinct comparison groups: Group 1-CA-MHB Tris vs. CA-MHB Tris $+\mathrm{NaHCO}_{3}$; and Group 2-CA-MHB Tris $+2 \% \mathrm{NaCl}+\mathrm{OXA}$ vs. CA-MHB Tris $+\mathrm{NaHCO}_{3}+2 \% \mathrm{NaCl}+$ OXA. RNA-seq analysis of the prototypical $\mathrm{NaHCO}_{3}$-responsive strain MRSA 11/11 revealed that exposure to $\mathrm{NaHCO}_{3}$ alone (Group 1) led to the differential change in abundance ( $\geq 2$-fold change) of 21 transcripts (Figure 1A); in contrast, $\mathrm{NaHCO}_{3}$-OXA combination (Group 2) yielded a differential change in abundance of 84 transcripts (Figure 1B). Following initial analysis of differentially abundant transcripts for Groups 1 and 2 in MRSA 11/11 and COL, those genes whose expression was altered in the same direction for both MRSA 11/11 and COL in each group were subtracted from subsequent analyses, as presented in Table 1.
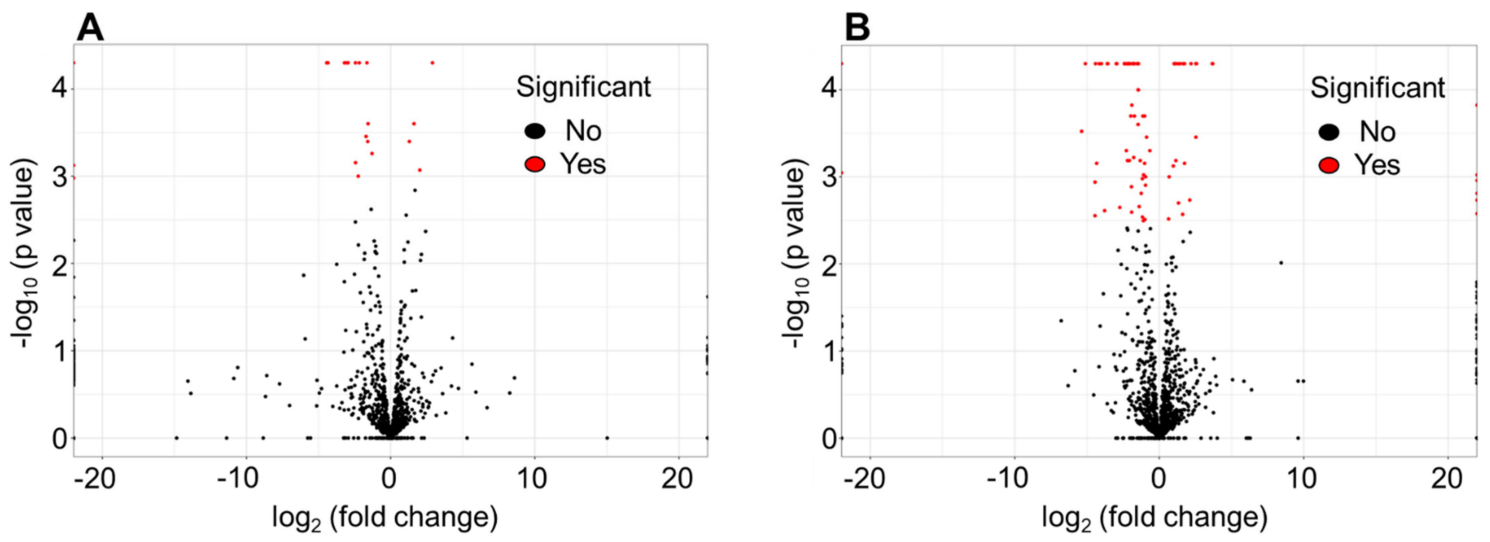

Figure 1. Volcano plots of the differential expression of genes in the presence of: (A) $\mathrm{NaHCO}_{3}$ exposure alone; or (B) $\mathrm{NaHCO}_{3}+\frac{1}{2}$ xMIC OXA co-exposures in $\mathrm{NaHCO}_{3}$-responsive strain MRSA 11/11. $\mathrm{NaHCO}_{3}$ alone led to an observed 21 differentially expressed transcripts. $\mathrm{NaHCO}_{3}$ and OXA co-exposures together yielded 84 differentially expressed transcripts. These numbers represent the total number of transcripts identified, featuring genes of both known and unknown functions.

Table 1. Overview of gene functional classes altered $\geq 2$-fold in two comparison groups, (Group 1) CA-MHB Tris vs. CA-MHB Tris $+\mathrm{NaHCO}_{3}$, and (Group 2) CA-MHB Tris $+2 \% \mathrm{NaCl}+\mathrm{OXA}$ vs. CA-MHB Tris $+\mathrm{NaHCO}_{3}+2 \% \mathrm{NaCl}+\mathrm{OXA}$. Genes/transcriptional units indicated in this tables are those altered by $\mathrm{NaHCO}_{3}$ exposure alone (Group 1, $n=11$ ), $\mathrm{NaHCO}_{3}$ and OXA co-exposure (Group 2, $n=57$ ), or common to both groups (Group 1 and 2,n=10) for a total number of functionally identifiable genes/transcriptional units of 78. "Increase" and "decrease" refer to expression being increased or decreased by exposure to $\mathrm{NaHCO}_{3}$ compared to media without $\mathrm{NaHCO}_{3}$ in each comparison group.

\begin{tabular}{cccc}
\hline $\begin{array}{c}\text { Classifications of Gene } \\
\text { Functions }\end{array}$ & $\begin{array}{c}\text { Number of } \\
\text { Genes/Transcriptional } \\
\text { Units Per Category }\end{array}$ & Number Increased & Number Decreased \\
Virulence & 12 & 2 & 10 \\
Cell Wall Synthesis & 10 & 1 & 9 \\
Membrane & 19 & 4 & 15 \\
Metabolism & 22 & 12 & 4 \\
Transcription & 5 & 5 & 1 \\
Translation & 6 & 2 & 0 \\
Transposition & 2 & 1 & 1 \\
Stress Response & 2 & 28 & 50 \\
\hline Totals: & 78 & & \\
\hline
\end{tabular}


$\mathrm{NaHCO}_{3}$ exposure, in the presence and absence of $\beta$-lactam co-exposure, impacted the expression of genes across a range of functional groups, with a large proportion relating to either cell wall synthesis, cell membrane transporters, or cellular metabolism (Table 1). Intriguingly, across most functional categories, $\mathrm{NaHCO}_{3}$ exposure resulted in significant repression of gene expression, particularly for those genes relating to virulence, cell wall biosynthesis, and membrane transporters (Table 1, Table S2A-C). Of the genes that were upregulated by $\mathrm{NaHCO}_{3}$ exposure, these tended to be related to cellular metabolism, protein translation, and/or stress response, indicating that $\mathrm{NaHCO}_{3}$ may mirror the exposure of the responsive MRSA strain to an 'inhospitable' host environment.

Oxidative and membrane stress have been implicated in the formation of persister cells [25], which make up approximately $1 \%$ of the total cell population; such cells have increased antibiotic tolerance and reduced metabolism [26-28]. The RNA-seq data above indicate that, while $\mathrm{NaHCO}_{3}$ may be stimulating a stress response in $\mathrm{NaHCO}_{3}$-responsive MRSA, $\mathrm{NaHCO}_{3}$ also evoked increased expression of many metabolic genes as compared to cells grown in the absence of $\mathrm{NaHCO}_{3}$. This latter finding (i.e., enhanced metabolic activity) would not support the notion of $\mathrm{NaHCO}_{3}$-mediated entry of responsive MRSA cells into a persister state (Table 1 , Table S2A-C).

We then interrogated only those differentially abundant transcriptional units that were specifically altered in MRSA $11 / 11$, and for which a specific function is known and expression was altered by $\geq 5$-fold. $\mathrm{NaHCO}_{3}$ alone significantly impacted the expression at this magnitude of only a relatively small number of functionally-identifiable genes/transcriptional units $(n=7)$ as compared to a larger number of genes/transcriptional units differentially impacted by $\mathrm{NaHCO}_{3}+\mathrm{OXA}(\mathrm{n}=14)$ in the $\mathrm{NaHCO}_{3}$-responsive strain MRSA 11/11 (Figure 2). Additionally, eight transcriptional units were differentially expressed in both growth conditions $\left(\mathrm{NaHCO}_{3}\right.$ alone and $\left.\mathrm{NaHCO}_{3}+\mathrm{OXA}\right)$ (Figure 2).

\section{MRSA 11/11 ( $\mathrm{NaHCO}_{3}$-Responder)}

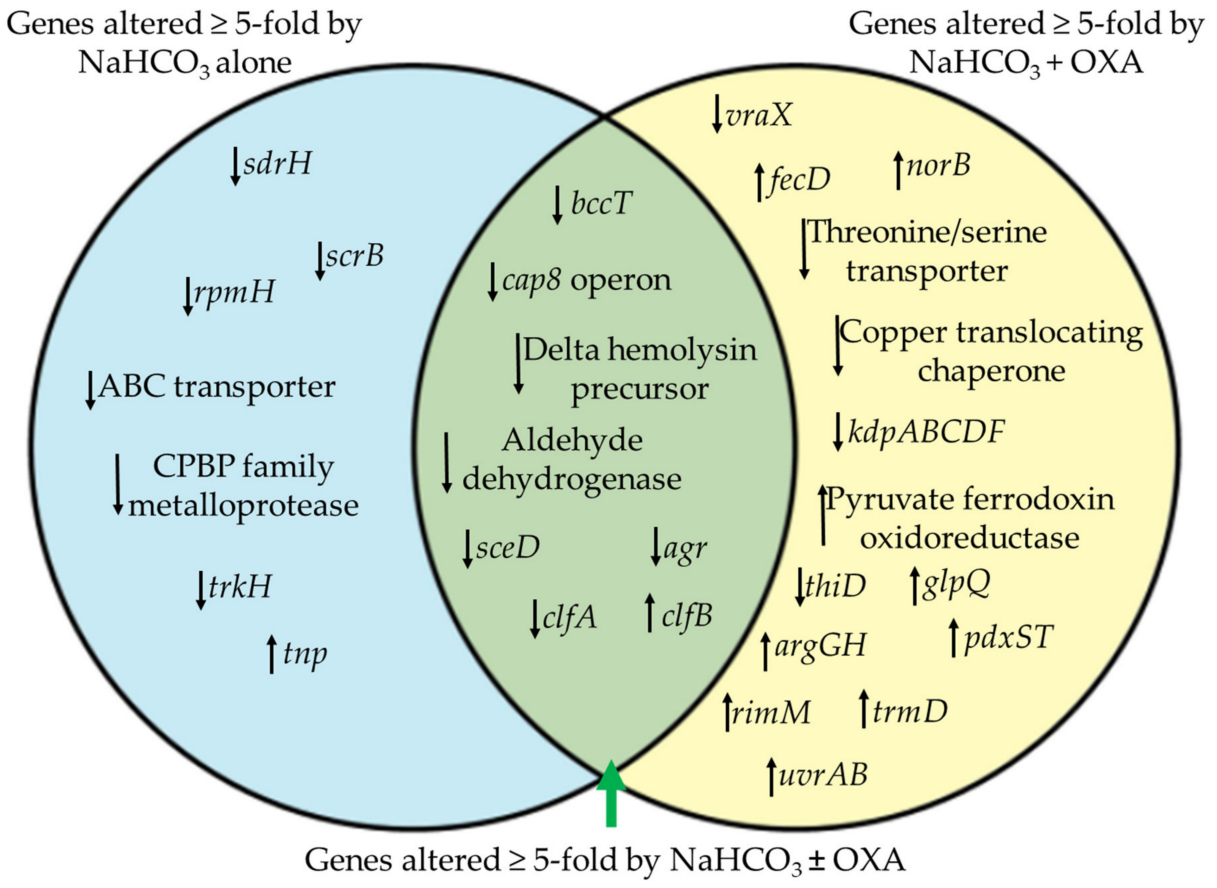

Figure 2. Venn diagram of genes altered $\geq 5$-fold by $\mathrm{NaHCO}_{3}$ exposure without (left) or with (right) OXA exposure specifically in $\mathrm{NaHCO}_{3}$-responsive strain MRSA 11/11. Arrows indicate whether expression was decreased (downward arrow) or increased (upward arrow) by $\mathrm{NaHCO}_{3}$ exposure. OXA exposure is equivalent to $\frac{1}{2} \times$ MIC of OXA in CA-MHB Tris $+2 \% \mathrm{NaCl} \pm \mathrm{NaHCO}_{3}$.

Of particular interest, the autolysin $s c e D$ and the global virulence regulator agr were both substantially repressed ( $\geq$ 5-fold change in expression) by $\mathrm{NaHCO}_{3}$, with or without 
$\beta$-lactam co-exposure (Figure 2, Table 2). The agr locus is a major virulence regulator in $S$. aureus [29-31], although its role in antibiotic resistance in vivo remains controversial [30,32]. Previously, we observed by qRT-PCR that $\mathrm{NaHCO}_{3}$ is capable of repressing the global virulence regulons sar $A$ and $\operatorname{sig} B$ (both agr-regulated) $[15,18]$. These RNA-seq data corroborate the downstream effects of $\operatorname{sar} A$ and sigB repression, as observed by the repression of $a g r$ and several other genes known to be part of the $\operatorname{sig} B$-sar $A$-agr regulon, including $f n b A$, fnbB, cap8, clfA, and $c l p L$ (Table 2, Table 3) [33-36]. Of note, one of the few genes upregulated by $\mathrm{NaHCO}_{3}$ exposure in MRSA 11/11 was clfB, a cell wall-anchored (CWA) protein whose function is linked to nasal colonization and virulence in skin and soft tissue infections [37]. Additionally, $\mathrm{NaHCO}_{3}$ repressed expression of $s d r \mathrm{H}$, another $\mathrm{CWA}$ gene whose repression is associated with decreased biofilm formation $[38,39]$, an impact that corresponds to the observed decrease in biofilm formation during $\mathrm{NaHCO}_{3}$ exposure in MRSA 11/11 [40]. Taken together, these data indicate a broad impact of $\mathrm{NaHCO}_{3}$ (especially in combination with OXA) on genes associated with cell surface modifications, as well as cell wall biosynthesis or remodeling.

Table 2. Genes of interest selectively altered in $\mathrm{NaHCO}_{3}$-responsive strain $\mathrm{MRSA} 11 / 11\left(\log _{2}\right.$ fold change $\left.{ }^{\mathrm{A}}\right)$.

\begin{tabular}{|c|c|c|c|c|}
\hline Gene Name & Locus Tag & $\begin{array}{c}+\mathrm{NaHCO}_{3} \\
\text { (no OXA) }\end{array}$ & $\begin{array}{c}+\mathrm{NaHCO}_{3} \\
\text { with } \mathrm{OXA}^{\mathrm{B}}\end{array}$ & Function \\
\hline clfA & SAUSA300_0772 & -2.18 & -2.97 & \multirow{6}{*}{ virulence } \\
\hline clfB & SAUSA300_2565 & 1.29 & 1.11 & \\
\hline$a g r$ & SAUSA300_1989 & -3.21 & -5.37 & \\
\hline$s d r H$ & SAUSA300_1985 & -2.44 & 0.00 & \\
\hline$f n b A$ & SAUSA300_2441 & 0.00 & -1.84 & \\
\hline$f n b B$ & SAUSA300_2440 & 0.00 & -1.47 & \\
\hline atl & SAUSA300_0955 & -1.65 & -2.93 & \multirow{3}{*}{ autolysins } \\
\hline$s c e D$ & SAUSA300_2051 & -6.53 & -4.41 & \\
\hline is $a A$ & SAUSA300_2506 & 0.00 & -2.12 & \\
\hline fmt $A$ & SAUSA300_0959 & 0.00 & -1.32 & \multirow{3}{*}{$\begin{array}{l}\text { peptidoglycan/cell } \\
\text { wall synthesis }\end{array}$} \\
\hline$d d h$ & SAUSA300_2463 & 0.00 & -4.00 & \\
\hline$p b p 2$ & SAUSA300_1341 & 0.00 & -1.81 & \\
\hline$b c c T$ & SAUSA300_2549 & -2.45 & -2.42 & osmotic stress \\
\hline$u s p$ & SAUSA300_0067 & -1.30 & -2.28 & stress response \\
\hline
\end{tabular}

${ }^{\mathrm{A}}$ Fold change comparisons are made by comparing the gene expression for the indicated strain and condition $( \pm \mathrm{OXA})$ exposed to $\mathrm{NaHCO}$ to the same strain/condition without $\mathrm{NaHCO}_{3}$ exposure. Negative values indicate that exposure to $\mathrm{NaHCO}_{3}$ for the given strain/condition decreases expression of the indicated gene, whereas positive values indicate that $\mathrm{NaHCO}_{3}$ increases expression of the indicated gene. ${ }^{\mathrm{B}}$ OXA concentration equal to $1 / 2 \times$ MIC in CA-MHB Tris \pm NaHCO3 for the indicated strain.

Table 3. Genes of interest altered in both $\mathrm{NaHCO}_{3}$-responsive and non-responsive strains $\left(\log _{2}\right.$ fold change $\left.{ }^{\mathrm{A}}\right)$.

\begin{tabular}{|c|c|c|c|c|c|c|}
\hline Gene Name & Locus Tag & $\begin{array}{c}\text { MRSA 11/11 } \\
+\mathrm{NaHCO}_{3} \text { (no } \\
\text { OXA) }\end{array}$ & $\begin{array}{c}\mathrm{COL} \\
+\mathrm{NaHCO}_{3} \text { (no } \\
\text { OXA) }\end{array}$ & $\begin{array}{c}\text { MRSA } \\
+\mathrm{NaHCO}_{3} \text { with } \\
\mathrm{OXA}^{\text {B }}\end{array}$ & $\begin{array}{c}\mathrm{COL} \\
+\mathrm{NaHCO}_{3} \text { with } \\
\mathrm{OXA}^{\mathrm{B}}\end{array}$ & Function \\
\hline cap8 & SAUSA300_0152 & -3.05 & 2.36 & -4.45 & 0.00 & \multirow{6}{*}{ virulence } \\
\hline$c l p L$ & SAUSA300_2486 & 0.00 & 0.00 & -1.44 & -1.46 & \\
\hline $\operatorname{sas} D$ & SAUSA300_0136 & 0.00 & 0.90 & 2.11 & -1.82 & \\
\hline$a a a$ & SAUSA300_0438 & 0.00 & -1.14 & -2.20 & 0.00 & \\
\hline vraX & SAUSA300_RS03005 & 0.00 & 0.00 & -4.45 & 1.88 & \\
\hline$k d p A B C D F$ & SAUSA300_2032 & 0.00 & 0.90 & -2.07 & 1.79 & \\
\hline bet $A B$ & SAUSA300_2545 & -4.44 & -1.38 & -5.12 & -4.28 & \multirow{3}{*}{$\begin{array}{l}\text { osmotic stress } \\
\text { transcriptional } \\
\text { regulator }\end{array}$} \\
\hline$i c a R$ & SAUSA300_2599 & 0.00 & 1.87 & 1.62 & 0.00 & \\
\hline$r s p$ & SAUSA300_2326 & -1.60 & -1.02 & 0.00 & 0.00 & \\
\hline
\end{tabular}

A Fold change comparisons are made by comparing the gene expression for the indicated strain and condition ( \pm OXA) exposed to $\mathrm{NaHCO}_{3}$ to the same strain/condition without $\mathrm{NaHCO}_{3}$ exposure. Negative values indicate that exposure to $\mathrm{NaHCO}_{3}$ for the given strain/condition decreases expression of the indicated gene, whereas positive values indicate that $\mathrm{NaHCO}_{3}$ increases expression of the indicated gene. ${ }^{\mathrm{B}} \mathrm{OXA}$ concentration equal to $1 / 2 \times$ MIC in CA-MHB Tris $\pm \mathrm{NaHCO} 3$ for the indicated strain.

It should be underscored that $\mathrm{NaHCO}_{3}$ did increase the expression of several genes in the non-responsive strain, COL, whose expressions were down-regulated in MRSA 11/11, including the cap8 operon, the virulence-associated gene vraX, and the potassium transport 
operon $k d p A B C D F$ (Table 3). Despite these observed differences in such putative virulence gene expressions between COL and MRSA 11/11, we have not observed any differences in the intrinsic virulence of these two strains in vivo [15]. Further, a large cadre of genes was specifically impacted by $\mathrm{NaHCO}_{3}$, with or without OXA exposure in strain COL, but not in MRSA 11/11. However, the analytics required to determine the role of these specifically and differentially impacted genes in generating the non-responsive MRSA phenotype is beyond the scope of this paper.

Of primary interest in regard to $\mathrm{NaHCO}_{3}$-mediated susceptibility to $\beta$-lactams was its impact on the expression of genes related to cell wall synthesis. $\mathrm{NaHCO}_{3}$ (with or without OXA co-exposure) repressed the expression of two key autolysins, atl and $s c e D$; in addition, the expressions of several other key genes involved in cell wall synthesis were repressed by $\mathrm{NaHCO}_{3}$-OXA co-exposures (isaA, fmt $A$, $d d h, p b p 2$ ) (Table 2). These latter six genes encompass those involved in the formation of nascent (new) peptidoglycan and cell wall restructuring ( $p b p 2, d d h, f m t A)$ [41-44], as well as peptidoglycan hydrolases, involved in cell wall turnover and division (atl, sceD, isaA) [45-47]. Previous studies have demonstrated that the deletion or inactivation of $i s a A$ and $f m t A$ results in increased susceptibility to $\beta$ lactams, an event independent of impacts on the expression of PBP2a $[45,48]$. Furthermore, the regulation of $s c e D$ and is $A$ transcription is linked, since deletion in is $A$ A results in enhanced expression of $s c e D[45,46]$. We observed a modest decrease in isa $A$ transcription in the presence of $\mathrm{NaHCO}_{3}-\mathrm{OXA}$, but a substantial decrease in $s c e D$ transcription in the presence of $\mathrm{NaHCO}_{3}$ (with or without OXA). Although previous reports did not find that the deletion of $s c e D$ alone resulted in increased $\beta$-lactam susceptibility [45], it is possible that within the context of the gene expression profile stimulated by $\mathrm{NaHCO}_{3}$, reduced sceD expression may have a larger impact on $\beta$-lactam susceptibility than previously understood.

\section{2. qRT-PCR Validation}

The qRT-PCR validation of specific genes identified by RNA-seq revealed that $s c e D$ expression was strongly repressed by $\mathrm{NaHCO}_{3}$ in MRSA $11 / 11$, while being substantially upregulated in the non-responsive strain COL (Figure 3); this finding further supports the notion that altered $s c e$ D expression may be of key importance to the $\mathrm{NaHCO}_{3}$-responsive phenotype. The qRT-PCR also validated the $\mathrm{NaHCO}_{3}$-mediated repression of $p b p 2$, atl, and fnbA in responsive strain MRSA $11 / 11$ as seen by RNA-seq, while $\mathrm{NaHCO}_{3}$ stimulated increased expression of these genes in COL (Figure 3).

\subsection{Limitations of Study}

This study was limited by only using a single $\mathrm{NaHCO}_{3}$-responsive/non-responsive strain pair for RNA-seq analyses. A larger number of strains exhibiting each phenotype would increase the likelihood of identifying a more consensus cadre of differentially expressed genes involved in the $\mathrm{NaHCO}_{3}$-responsiveness phenotype. Further, only one $\beta$ lactam (OXA) was tested for its impact on gene expression in the presence of $\mathrm{NaHCO}_{3}$. Our previous work has demonstrated that $\mathrm{NaHCO}_{3}$-induced sensitization to cefazolin (CFZ) is much more frequent among MRSA strains than sensitization to OXA [16]. This implies that CFZ and OXA may be impacting somewhat different genetic targets in $\mathrm{NaHCO}_{3}$-responsive strains, which could be causing the increased frequency of sensitization to CFZ vs. OXA. Additionally, only one concentration of $\mathrm{NaHCO}_{3}(44 \mathrm{mM})$ was examined for its impact on gene expression. Investigating the impact of $\mathrm{NaHCO}_{3}$ at blood concentrations $(\sim 25 \mathrm{mM}$ $\mathrm{NaHCO}_{3}$ ) may reveal genes that are particularly important to $\mathrm{NaHCO}_{3}-\beta$-lactam-induced changes in expression within that specific host microenvironment.

Although KEGG analysis was carried out, the relatively small number of differentially expressed genes in MRSA 11/11 limited the number that could be functionally categorized to a selected, definable metabolic or biosynthetic pathway. The relative lack of descriptive KEGG pathways to ascribe to the differentially transcribed genes in these analyses underscores the need for separate functional characterizations of those genes we have identified by RNA-seq. Furthermore, additional investigations with a larger collection of 
$\mathrm{NaHCO}_{3}$-responsive strains may help in determining specific, consensus KEGG pathways associated with the responsive phenotype.
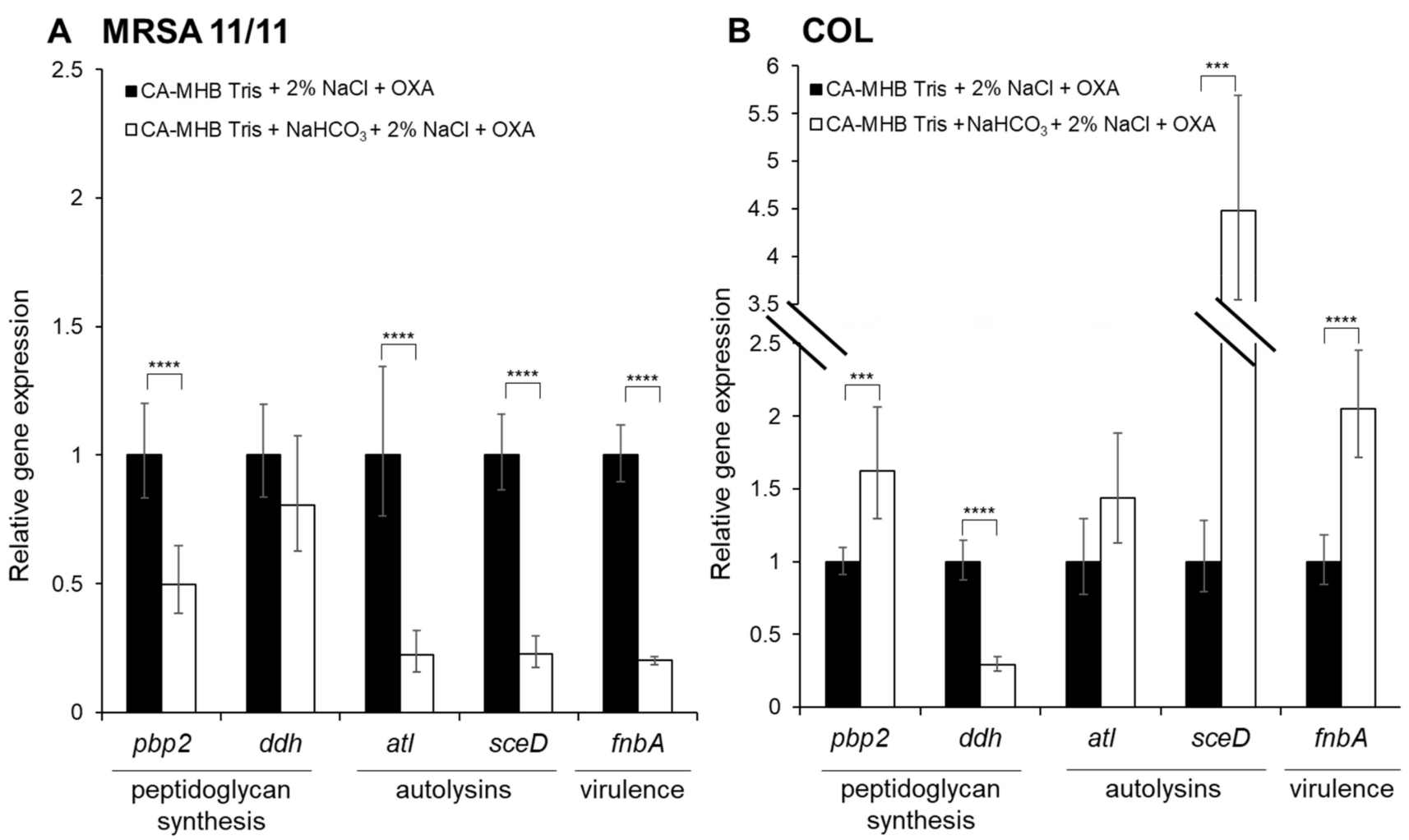

Figure 3. qRT-PCR confirmation of the expression of key genes-of-interest from RNA-seq analysis in: (A) MRSA 11/11, $\mathrm{NaHCO}_{3}$-responsive strain; and (B) COL, non-responsive strain. Expression was determined in log phase MRSA 11/11 and COL strains, each grown in the presence of $\frac{1}{2} \times$ MIC OXA. For each gene, expression is normalized to that observed for the indicated strain grown in CA-MHB Tris $+2 \% \mathrm{NaCl}+\frac{1}{2} \times \mathrm{MIC}$ OXA (CA-MHB Tris $+2 \% \mathrm{NaCl}+\frac{1}{2} \times \mathrm{MIC}$ OXA expression set at 1.0). Statistics were calculated by Student's $t$-test ( $\left.{ }^{* * *} P<0.001,{ }^{* * * *} P<0.0001\right)$.

\section{Conclusions}

$\mathrm{NaHCO}_{3}$ (especially in combination with OXA) impacts a variety of genes specifically and differentially expressed in the $\mathrm{NaHCO}_{3}$-responsive strain MRSA 11/11 relating to: cell wall synthesis, turn-over and division; and cell surface-associated genes regulated by the sigB-sar $A$-agr regulatory axis. These analyses point to a mechanism of $\beta$-lactam sensitization by $\mathrm{NaHCO}_{3}$ that involves global impacts on the cell surface (where $\beta$-lactams initially bind), as well as altered expression of genes required to synthesize the cell wall and maintain its homeostasis. Moreover, further work is needed to validate and quantify the specific impact of those genes identified herein on the $\mathrm{NaHCO}_{3}$-responsive phenotype, using strategic gene knockouts. Finally, future studies will be designed to look at the differential impacts of $\mathrm{NaHCO}_{3}$ upon protein-level expression profiles in $\mathrm{NaHCO}_{3}$-responsive vs. non-responsive MRSA.

Supplementary Materials: The following are available online at https: / www.mdpi.com/article/10 .3390 /genes12111650/s1, Table S1: qRT-PCR primers, Table S2: (A) Genes altered $\geq 2$-fold by CAMHB $100 \mathrm{mM}$ Tris $+44 \mathrm{mM} \mathrm{NaHCO}_{3}$ exposure (without oxacillin) compared to CA-MHB $100 \mathrm{mM}$ Tris alone (without oxacillin) specifically in $\mathrm{NaHCO}_{3}$-responsive strain MRSA 11/11, (B) Genes altered $\geq 2$-fold by CA-MHB $100 \mathrm{mM}$ Tris $+44 \mathrm{mM} \mathrm{NaHCO}_{3}$ with oxacillin exposure compared to CA-MHB $100 \mathrm{mM}$ Tris alone with oxacillin exposure specifically in $\mathrm{NaHCO}_{3}$-responsive strain MRSA 11/11, (C) Genes altered $\geq 2$-fold by CA-MHB $100 \mathrm{mM}$ Tris $+44 \mathrm{mM} \mathrm{NaHCO}_{3}$ exposure ( \pm oxacillin) compared to CA-MHB $100 \mathrm{mM}$ Tris alone ( \pm oxacillin) specifically in $\mathrm{NaHCO}_{3}$-responsive strain MRSA 11/11. 
Author Contributions: Conceptualization, S.C.E., B.M.H., C.A.A., R.A.P., and A.S.B.; methodology, S.C.E., B.M.H., and T.T.T.; software, B.M.H.; formal analysis, S.C.E., B.M.H., and R.A.P.; writingoriginal draft preparation, S.C.E., B.M.H., and A.S.B.; writing-review and editing, S.C.E., B.M.H., R.A.P., H.F.C., and A.S.B.; supervision, A.S.B.; project administration, C.A.A., A.S.B.; funding acquisition, B.M.H. and A.S.B. All authors have read and agreed to the published version of the manuscript.

Funding: This project was supported by the following grants from the National Institutes of Health: 1R01-AI146078 (to ASB), K01-AI148593 (to BMH), 1R01-AI134637 (to CAA), 1R01-AI148342 (to CAA), K24-AI121296 (to CAA), and P01-AI152999 (to CAA).

Institutional Review Board Statement: Not applicable.

Informed Consent Statement: Not applicable.

Data Availability Statement: The data presented in this study are openly available in the NCBI Sequence Read Archive (SRA) as indicated in the manuscript materials and methods.

Conflicts of Interest: The authors declare no conflict of interest.

\section{References}

1. CDC. Antibiotic Resistance Threats in the United States, 2019; U.S. Deppartment of Health and Human Services, CDC: Atlanta, GA, USA, 2019.

2. Ventola, C.L. The antibiotic resistance crisis: Part 1: Causes and threats. Pharm. Ther. 2015, 40, 277.

3. Abadi, A.T.B.; Rizvanov, A.A.; Haertlé, T.; Blatt, N.L. World Health Organization report: Current crisis of antibiotic resistance. BioNanoScience 2019, 9, 778-788. [CrossRef]

4. WHO. Antimicrobial resistance: Global report on surveillance; World Health Organization: Geneva, Switzerland, 2014.

5. Grundmann, H.; Aires-de-Sousa, M.; Boyce, J.; Tiemersma, E. Emergence and resurgence of meticillin-resistant Staphylococcus aureus as a public-health threat. Lancet 2006, 368, 874-885. [CrossRef]

6. Goetghebeur, M.; Landry, P.-A.; Han, D.; Vicente, C. Methicillin-resistant Staphylococcus aureus: A public health issue with economic consequences. Can. J. Infect. Dis. Med. Microbiol. 2007, 18, 27-34. [CrossRef]

7. Hassoun, A.; Linden, P.K.; Friedman, B. Incidence, prevalence, and management of MRSA bacteremia across patient populationsa review of recent developments in MRSA management and treatment. Crit. Care 2017, 21, 211. [CrossRef] [PubMed]

8. Gould, I.; Reilly, J.; Bunyan, D.; Walker, A. Costs of healthcare-associated methicillin-resistant Staphylococcus aureus and its control. Clin. Microbiol. Infect. 2010, 16, 1721-1728. [CrossRef]

9. Purrello, S.; Garau, J.; Giamarellos, E.; Mazzei, T.; Pea, F.; Soriano, A.; Stefani, S. Methicillin-resistant Staphylococcus aureus infections: A review of the currently available treatment options. J. Glob. Antimicrob. Resist. 2016, 7, 178-186. [CrossRef]

10. Edwards, B.; Andini, R.; Esposito, S.; Grossi, P.; Lew, D.; Mazzei, T.; Novelli, A.; Soriano, A.; Gould, I. Treatment options for methicillin-resistant Staphylococcus aureus (MRSA) infection: Where are we now? J. Glob. Antimicrob. Resist. 2014, 2, 133-140. [CrossRef]

11. Bamgbola, O. Review of vancomycin-induced renal toxicity: An update. Ther. Adv. Endocrinol. Metab. 2016, 7, 136-147. [CrossRef]

12. Abraham, G.; Finkelberg, D.; Spooner, L.M. Daptomycin-induced acute renal and hepatic toxicity without rhabdomyolysis. Ann. Pharmacother. 2008, 42, 719-721. [CrossRef]

13. McConeghy, K.W.; Bleasdale, S.C.; Rodvold, K.A. The empirical combination of vancomycin and a $\beta$-lactam for staphylococcal bacteremia. Clin. Infect. Dis. 2013, 57, 1760-1765. [CrossRef]

14. Kim, S.-H.; Kim, K.-H.; Kim, H.-B.; Kim, N.-J.; Kim, E.-C.; Oh, M.-D.; Choe, K.-W. Outcome of vancomycin treatment in patients with methicillin-susceptible Staphylococcus aureus bacteremia. Antimicrob. Agents Chemother. 2008, 52, 192-197. [CrossRef]

15. Ersoy, S.C.; Abdelhady, W.; Li, L.; Chambers, H.F.; Xiong, Y.Q.; Bayer, A.S. Bicarbonate resensitization of methicillin-resistant Staphylococcus aureus to $\beta$-lactam antibiotics. Antimicrob. Agents Chemother. 2019, 63, e00496-19. [CrossRef] [PubMed]

16. Ersoy, S.C.; Otmishi, M.; Milan, V.T.; Li, L.; Pak, Y.; Mediavilla, J.; Chen, L.; Kreiswirth, B.; Chambers, H.F.; Proctor, R.A.; et al. Scope and predictive genetic/phenotypic signatures of 'bicarbonate $\left[\mathrm{NaHCO}_{3}\right]$-responsiveness' and $\beta$-Lactam sensitization among methicillin-resistant Staphylococcus aureus (MRSA). Antimicrob. Agents Chemother. 2020, 5, e02445-19. [CrossRef]

17. Rose, W.E.; Bienvenida, A.M.; Xiong, Y.Q.; Chambers, H.F.; Bayer, A.S.; Ersoy, S.C. Ability of bicarbonate supplementation to sensitize selected methicillin-resistant Staphylococcus aureus (MRSA) strains to $\beta$-lactam antibiotics in an Ex Vivo simulated endocardial vegetation model. Antimicrob. Agents Chemother. 2019, 64, e02072-19.

18. Ersoy, S.C.; Chambers, H.F.; Proctor, R.A.; Rosato, A.E.; Mishra, N.N.; Xiong, Y.Q.; Bayer, A.S. Impact of bicarbonate on PBP2a production, maturation, and functionality in methicillin-resistant Staphylococcus aureus. Antimicrob. Agents Chemother. 2021, 65, e02621-20. [CrossRef]

19. Ersoy, S.C.; Heithoff, D.M.; Barnes, L.; Tripp, G.K.; House, J.K.; Marth, J.D.; Smith, J.W.; Mahan, M.J. Faculty opinions recommendation of correcting a fundamental flaw in the paradigm for antimicrobial susceptibility testing. EBioMedicine 2019, 20, 173-181. [CrossRef]

20. Fenn, W.O. The carbon dioxide dissociation curve of nerve and muscle. Am. J. Physiol. Leg. Content 1928, 85, 207-223. [CrossRef] 
21. Bolger, A.M.; Lohse, M.; Usadel, B. Trimmomatic: A flexible trimmer for Illumina sequence data. Bioinformatics 2014, 30, 2114-2120. [CrossRef] [PubMed]

22. Langmead, B.; Salzberg, S.L. Fast gapped-read alignment with Bowtie 2. Nat. Methods 2012, 9, 357-359. [CrossRef]

23. Trapnell, C.; Roberts, A.; Goff, L.; Pertea, G.; Kim, D.; Kelley, D.R.; Pimentel, H.; Salzberg, S.L.; Rinn, J.L.; Pachter, L. Differential gene and transcript expression analysis of RNA-seq experiments with TopHat and Cufflinks. Nat. Protoc. 2012, 7, 562-578. [CrossRef]

24. Bu, D.; Luo, H.; Huo, P.; Wang, Z.; Zhang, S.; He, Z.; Wu, Y.; Zhao, L.; Liu, J.; Guo, J.; et al. KOBAS-i: Intelligent prioritization and exploratory visualization of biological functions for gene enrichment analysis. Nucleic Acids Res. 2021, 49, W317-W325. [CrossRef]

25. Sahukhal, G.S.; Pandey, S.; Elasri, M.O. MsaABCR operon is involved in persister cell formation in Staphylococcus aureus. BMC Microbiol. 2017, 17, 218. [CrossRef]

26. Grassi, L.; Di Luca, M.; Maisetta, G.; Rinaldi, A.C.; Esin, S.; Trampuz, A.; Batoni, G. Generation of persister cells of Pseudomonas aeruginosa and Staphylococcus aureus by chemical treatment and evaluation of their susceptibility to membrane-targeting agents. Front. Microbiol. 2017, 8, 1917. [CrossRef] [PubMed]

27. Lewis, K. Persister cells, dormancy and infectious disease. Nat. Rev. Genet. 2006, 5, 48-56. [CrossRef]

28. Tuchscherr, L.; Löffler, B.; Proctor, R.A. Persistence of Staphylococcus aureus: Multiple metabolic pathways impact the expression of virulence factors in small-colony variants (SCVs). Front. Microbiol. 2020, 11, 1028. [CrossRef]

29. Traber, K.E.; Lee, E.; Benson, S.; Corrigan, R.; Cantera, M.; Shopsin, B.; Novick, R.P. Agr function in clinical Staphylococcus aureus isolates. Microbiology 2008, 154, 2265. [CrossRef]

30. Seidl, K.; Chen, L.; Bayer, A.S.; Hady, W.A.; Kreiswirth, B.N.; Xiong, Y.Q. Relationship of agr expression and function with virulence and vancomycin treatment outcomes in experimental endocarditis due to methicillin-resistant Staphylococcus aureus. Antimicrob. Agents Chemother. 2011, 55, 5631-5639. [CrossRef]

31. Gupta, R.K.; Luong, T.T.; Lee, C.Y. RNAIII of the Staphylococcus aureus agr system activates global regulator MgrA by stabilizing mRNA. Proc. Natl. Acad. Sci. USA 2015, 112, 14036-14041. [CrossRef]

32. Montgomery, C.P.; Boyle-Vavra, S.; Daum, R.S. Importance of the global regulators Agr and SaeRS in the pathogenesis of CA-MRSA USA300 infection. PLoS ONE 2010, 5, e15177. [CrossRef]

33. Cheung, A.L.; Zhang, G. Global regulation of virulence determinants in Staphylococcus aureus by the SarA protein family. Front Biosci. 2002, 7, d1825-d1842. [CrossRef] [PubMed]

34. Bischoff, M.; Dunman, P.; Kormanec, J.; Macapagal, D.; Murphy, E.; Mounts, W.; Berger-Bächi, B.; Projan, S. Microarray-based analysis of the Staphylococcus aureus $\sigma B$ regulon. J. Bacteriol. 2004, 186, 4085-4099. [CrossRef] [PubMed]

35. Van Wamel, W.; Xiong, Y.-Q.; Bayer, A.; Yeaman, M.; Nast, C.; Cheung, A. Regulation of Staphylococcus aureus type 5 capsular polysaccharides by agr and sarA In Vitro and in an experimental endocarditis model. Microb. Pathog. 2002, 33, 73-79. [CrossRef] [PubMed]

36. Xiong, Y.-Q.; Bayer, A.S.; Yeaman, M.R.; Van Wamel, W.; Manna, A.C.; Cheung, A.L. Impacts of sarA and agr in Staphylococcus aureus strain newman on fibronectin-binding protein A gene expression and fibronectin adherence capacity In Vitro and in experimental infective endocarditis. Infect. Immun. 2004, 72, 1832-1836. [CrossRef]

37. Lacey, K.A.; Mulcahy, M.E.; Towell, A.M.; Geoghegan, J.A.; McLoughlin, R.M. Clumping factor B is an important virulence factor during Staphylococcus aureus skin infection and a promising vaccine target. PLoS Pathog. 2019, 15, e1007713. [CrossRef]

38. McCrea, K.W.; Hartford, O.; Davis, S.; Eidhin, D.N.; Lina, G.; Speziale, P.; Foster, T.J.; Höök, M. The serine-aspartate repeat (Sdr) protein family in Staphylococcus epidermidis. Microbiology 2000, 146, 1535-1546. [CrossRef]

39. Kong, C.; Chee, C.-F.; Richter, K.; Thomas, N.; Rahman, N.A.; Nathan, S. Suppression of Staphylococcus aureus biofilm formation and virulence by a benzimidazole derivative, UM-C162. Sci. Rep. 2018, 8, 1-16. [CrossRef]

40. Ersoy, S.C.; Abdelhady, W.; Li, L.; Xiong, Y.Q.; Bayer, A.S. Bicarbonate represses the sarA/mecA regulatory axis, re-sensitizing selected methicillin-resistant Staphylococcus aureus (MRSA) to $\beta$-lactam antibiotics. Gordon Research Conference on Staphylococcal Diseases, poster 36. Castelldefels, Spain, 4-9 August 2019.

41. Rahman, M.M.; Hunter, H.N.; Prova, S.; Verma, V.; Qamar, A.; Golemi-Kotra, D. Faculty opinions recommendation of the Staphylococcus aureus methicillin resistance factor FmtA is a d-amino esterase that acts on teichoic acids. mBio 2016, 7, 02070-15. [CrossRef]

42. Straume, D.; Piechowiak, K.W.; Kjos, M.; Håvarstein, L.S. Class A PBPs: It is time to rethink traditional paradigms. Mol. Microbiol. 2021, 116, 41-52. [CrossRef]

43. Łęski, T.A.; Tomasz, A. Role of penicillin-binding protein 2 (PBP2) in the antibiotic susceptibility and cell wall cross-linking of Staphylococcus aureus: Evidence for the cooperative functioning of PBP2, PBP4, and PBP2A. J. Bacteriol. 2005, 187, 1815-1824. [CrossRef]

44. Boyle-Vavra, S.; De Jonge, B.; Ebert, C.C.; Daum, R.S. Cloning of the Staphylococcus aureus ddh gene encoding NAD+-dependent dlactate dehydrogenase and insertional inactivation in a glycopeptide-resistant isolate. J. Bacteriol. 1997, 179, 6756-6763. [CrossRef]

45. Lopes, A.-A.; Yoshii, Y.; Yamada, S.; Nagakura, M.; Kinjo, Y.; Mizunoe, Y.; Okuda, K.-i. Roles of lytic transglycosylases in biofilm formation and $\beta$-lactam resistance in methicillin-resistant Staphylococcus aureus. Antimicrob. Agents Chemother. 2019, 63, e01277-19. [CrossRef]

46. Stapleton, M.R.; Horsburgh, M.J.; Hayhurst, E.J.; Wright, L.; Jonsson, I.-M.; Tarkowski, A.; Kokai-Kun, J.F.; Mond, J.J.; Foster, S.J. Characterization of IsaA and SceD, two putative lytic transglycosylases of Staphylococcus aureus. J. Bacteriol. 2007, 189, 7316-7325. [CrossRef] 
47. Biswas, R.; Martinez, R.E.; Göhring, N.; Schlag, M.; Josten, M.; Xia, G.; Hegler, F.; Gekeler, C.; Gleske, A.-K.; Götz, F. Protonbinding capacity of Staphylococcus aureus wall teichoic acid and its role in controlling autolysin activity. PLoS ONE 2012, 7, e41415. [CrossRef]

48. Zhao, Y.; Verma, V.; Belcheva, A.; Singh, A.; Fridman, M.; Golemi-Kotra, D. Staphylococcus aureus methicillin-resistance factor fmtA is regulated by the global regulator SarA. PLoS ONE 2012, 7, e43998. [CrossRef] 